\title{
Phytochemical and microbial analyses of Berberis sp. extracts
}

\author{
CORNELIA UNGUREAN ${ }^{1}$, RAHELA CARPA ${ }^{1,2 *}$, RAMONA CÂMPEAN³, \\ MARIA CORNELIA MAIOR ${ }^{4}$, NELI-KINGA OLAH ${ }^{3,5}$ \\ ${ }^{1}$ Babeş Bolyai University, Faculty of Biology and Geology, Molecular Biology and Biotechnology \\ Department, 1 M. Kogalniceanu street, 400084, Cluj-Napoca, Romania \\ ${ }^{2}$ Babeş Bolyai University, Centre of Systemic Biology, Biodiversity and Bioresources, 1 M. Kogalniceanu \\ street, 400084, Cluj-Napoca, Romania \\ ${ }^{3}$ SC. PlantExtrakt. SRL, Rădaia, fn, 407059, Cluj-Napoca, Romania \\ ${ }^{4}$ Babeş Bolyai University, Institute of Technology, Plant Biotechnology Department, 30 Fantanele street, \\ 400084, Cluj-Napoca, Romania \\ ${ }^{5}$ Vasile Goldis Western University from Arad, Faculty of Pharmacy, L. Rebreanu street, Arad, Romania
}

\begin{abstract}
In the near past the use of herbs for health enhanced and scientists are studying new anti-microbial phytochemicals. Although plants have a wide variety of secondary metabolites, very few are still used as antimicrobial. This study performes phytochemical and antibacterial analysis of ethanolic extracts from Berberis vulgaris and Berberis aquifolium.

Extracts were prepared from stem and root bark of Berberis sp. with $70 \%$ ethanol. After obtaining the plant extracts qualitative and quantitative phytochemical analysis were performed through spectrophotometry, thin layer chromatography, reversed phase HPLC and UV-VIS spectra. The results showed that $B$. aquifolium extract has a bigger concentration of alkaloids (5.555\%) than $B$. vulgaris extract $(4.161 \%)$. The analysis from reversed phase HPLC showed that berberine concentration in B. aquifolium is $0.515 \mathrm{mg} / \mathrm{ml}$ and in B. vulgaris extract is $1.369 \mathrm{mg} / \mathrm{ml}$, so in oregon grape is found a smaller concentration of berberine than in common barberry.

The plant extracts were tested on Escherichia coli (Gram negative) and Staphylococcus aureus (Gram positive) bacteria. We found inhibition between 10-12 mm on S. aureus and on E. coli between $8-10 \mathrm{~mm}$. The extracts exhibited a stronger activity versus $S$. aureus, which demonstrates that berberine extracts are usefull in treatment of infections.
\end{abstract}

Keywords Berberine, Berberis vulgaris, B. aquifolium, HPLC, bacterial susceptibility.

Abbreviation $\mathrm{HPLC}=$ high-performance liquid chromatography; TLC $=$ thin-layer chromatography; $\mathrm{HAB}=$ Homöopathisches Arzneibuch; MT = mother tincture.

To cite this article: UNGUREAN C, CARPA R, CÂMPEAN R, MAIOR MC, OLAH NK. Phytochemical and microbial analyses of Berberis sp. extracts. Rom Biotechnol Lett. 2020; 25(6): 2132-2139. DOI: $10.25083 / \mathrm{rbl} / 25.6 / 2132.2139$

*Corresponding author: RAHELA CARPA, Babeş Bolyai University, Faculty of Biology and Geology, Molecular Biology and Biotechnology Department, 1 M. Kogalniceanu street, 400084, Cluj-Napoca, Romania E-mail: $\underline{\mathrm{k} \_ \text {hella@yahoo.com }}$ 


\section{Introduction}

Biotechnology industries in the pharmaceutical or food domain gain many benefits from medicinal plants in order to manufacture different homeopathic remedies to treat different diseases. Many plants have secondary metabolites, located in several parts of the plant: root, stem, bark, leaf or fruits. Thus, the efficiency of the extracts is due to alkaloids which protect plants against any pathogenic attack. Berberine, is an isoquinoline alkaloid from plants, belongs to the protoberberines class and is one of the most studied naturally occurring protoberberine alkaloids (M. IMANSHAHIDI \& H. HOSSEINZADEH [1]; V. JYOTHILAKSHMI \& al [2]).

Berberis vulgaris L. is called barberry and is a shrub up to 2 meters high (F. CLINOVSCHI [3]). It is found in Central and Southern Europe, where it originates, NorthWest Africa and Western Asia (J. KLOSS [4]). The specific traits of barberry are the small and red fruits, persistent beyond frost, it has yellow flowers, small and oval leafs, slightly serrated, like having small thistles, and grouped 2 to 5 on the stem (L.S. MUNTEAN [5]).

Mahonia aquifolium Nutt. named mountain grape or Oregon grape (J.S. FRALISH \& S.B. FRANKLIN [6]), is a perennial plant belonging to Berberis genus and it originates in North America (F. CLINOVSCHI [3]). It is a tall shrub reaching heights of $1.5-2 \mathrm{~m}$. The specific traits of this shrub are the violet fruits grouped in clusters, the acute leaves, dark green in the summer and redish-blue in winter, bright and with lateral thistles bigger than B. vulgaris. The stem is woody, yellow and has long and sharp thorns. The bark has no smell, but a bitter taste (L.S. MUNTEAN [5]). Berberis aquifolium ranges in North America, starting from S-E Alaska and Northern California up to the West of United States (D.E. JONES [7]; C. ROSS [8]). This shrub prefers colder zones, being found at 2000 meters of altitude in woods, especially pine woods. It resists on any type of soil and can resist drought. It supports winter and is not pretentious about light, it can adapt both at shadow and bright places (D. KINDERSLEY \& C. BRICKELL [9]).

In the bark of root and stem of both plants is found a very important alkaloid of Berberis genus, berberine. Berberine (K. GHEDIRA \& P. GOETZ [10]) plays an important role in the plant activity from the root bark to the aerial organs (S. FAZEL \& al [11]). Berberine has antibacterial and antifungal properties and, due to this, some researchers have formulated drugs based on berberine which can treat diseases, such as psoriasis (P. ANDRES \& G. CHANTALAT [12]) or tipe II diabetes (A. CICERO \& S. ERTEK [13]).

In this paper, phytochemical studies are included and the antibacterial activity of ethanolic extracts from two medicinal plants, Berberis vulgaris and Berberis aquifolium, was assessed.

\section{Materials and Methods}

1. Extraction protocol from Berberis vulgaris and Berberis aquifolium. For this study were used the following tinctures: Berberis aquifolium $\mathrm{MT}=1$ Sin. Mahonia aquifolium according to $\mathrm{HAB}$ [14] and Berberis vulgaris $\mathrm{MT}=1$ according to HAB [15] from SC. PlantExtrakt SRL.
The bark of the root and stem of the plants was dried at shade 1-2 days, than was small grinded. The quality parameter was calculated by 1:7 ratio (1- plant; 7- alcohol) according to $\mathrm{HAB}$, and then the qunatity was stirred, cleaned and left to maceration in $70 \%$ alchool for 10 days. All extracts were stored in amber glass bottles at $4^{\circ} \mathrm{C}$ throughout the study period.

2. Berberine identification from B. vulgaris and $B$. aquifolium extracts by thin-layer chromatography (TLC). It allows the identification of alkaloids from a plant extract or tincture based on a standard. TLC is based on the principle of compounds separation from a mixture, based on their solubility and their interaction with the stationary phase.

Out of each tincture $20 \mu \mathrm{l}$ were taken, from $B$. Aquifolium extract and from $B$. vulgaris extract, and were applied on the silica gel plate $(7 \times 20 \mathrm{~cm})$. As standard was used berberine chloride $(20 \mu \mathrm{l})$ in methanol, $\mathrm{c}=1,2 \mathrm{mg} / \mathrm{ml}$. The inoculated plate was left to dry for 30 minutes under air jet. After drying, the plate was pulverized with berberine hydrochloride on all the surface and left to migrate about an hour, than dried in hood. The silica gel plate was analysed at UV-VIS spectrum at $254 \mathrm{~nm}, 365 \mathrm{~nm}$ and visible (HAB [14]; HAB [15]).

3. Identification of berberine from $B$. vulgaris and B. aquifolium extracts by spectrophotometry. In order to titrate the alkaloids expressed in berberine $2 \mathrm{~g}$ of product were taken and diluated at $100 \mathrm{ml}$ with sulphuric acid 0,05 $\mathrm{M}$ in methanol. For B. aquifolium $20 \mathrm{ml}$ were taken from solution and it was taken to $100 \mathrm{ml}$ with methanol, and for B. vulgaris $5 \mathrm{ml}$ were taken from the solution and diluted to $25 \mathrm{ml}$ with sulphuric acid $0.05 \mathrm{M}$ in methanol.

The blind sample was sulphuric acid $0,05 \mathrm{M}$ in methanol. The calculation formula for B. vulgaris was: \% alkaloids, expressed in berberine $=3.07 \times \mathrm{A} / \mathrm{m}(\mathrm{A}=$ sample absorbancy; $\mathrm{m}=$ mass of analyzed product, in grames). And for B. aquifolium it was: \% alkaloids, expressed in berberine $=0.613 \mathrm{~A} / \mathrm{m}(\mathrm{HAB}[14]$; HAB [15]). The absorbancy was read at $425 \mathrm{~nm}$.

4. Identification of berberine out of $B$. vulgaris and B. aquifolium extracts using High Performance Liquid Chromatography with reversed phase (HPLC). HPLC protocol was modified according to the protocol used by G.V. SRINIVASAN \& al. [16]. For analyzing the samples two solutions diluated 1:100 (extract:methanol) were prepared. Subsequent, the solutions were passed through a membrane filter (Hydrophilic PTFE Multipore MillexLCR), $0.45 \mu \mathrm{m}$ wide, 3 times, in a Rotilabo flask with brown glass fillet of $1 \mathrm{ml}$ and were introduced in the collector of the HPLC. In 2 flasks eluting solvents were introduced, in flask A was introduced purified water and in flask B was added a mixture of acetonitrile and water in 10:90 (v/v) ratio. In the HPLC programme with reversed phase the time and quantity injected were set. Thus, once at 8 minutes, were injected, in turn, 8, 12, 16, 20, 24, 28, $32 \mu \mathrm{l}$ of prepared samples. After dosage, the retention time was read from the chromatogram after $8.6 \mathrm{~min}$ and on chromatogram appeared the area of the peak for berberine at $266 \mathrm{~nm}$ for each sample.

Based on the value for the area the concentration of the alkaloid was calculated and the berberine quantity in 
the studied sample was established. The next formula was used: $C=\frac{A+2 \times 10^{6}}{3 \times 10^{7}}$, where $\mathrm{A}=$ the berberine area from B. vulgaris solution, respective B. aquifolium (HAB [14]; HAB [15]).

5. Disk paper method for testing the bacteria sensibility to Berberis sp. extracts - qualitative diffusimetric method. The susceptibility of the bacteria test (Staphylococcus aureus ATCC 25923, Gram pozitive and Escherichia coli ATCC 25922, Gram negative) to plant extracts was determined using a paper disc diffusion assay on Nutrient Agar plates (R.M. ATLAS [17]), following the method described by R. CARPA \& al. [18] and by G. PAUN \& al. [19]. Diluted bacterial cultures were adjusted to 0.5 McFarland turbidity (1-2 x $\left.10^{6} \mathrm{cfu} \mathrm{ml}^{-1}\right)$ and spread evenly over the entire surface of the agar plates using a sterile cotton swab. The plates were allowed to air-dry for approximately $10 \mathrm{~min}$ before paper disc $(6 \mathrm{~mm})$ were place on the agar plate. Each extract test was replicated three times. The plates were incubated at $37^{\circ} \mathrm{C}$ for $22-24 \mathrm{~h}$ period. For each microorganism tested, zones of inhibition of growth were examined, and the diameter of each zone was measured and recorded.

\section{Results and Discussion}

1. Spectrophotometric analysis of Berberis vulgaris and Berberis aquifolium tinctures. The measurement of the absorption degree of the sample for the incident radiation was done at the wave length of $425 \mathrm{~nm}$. In the Fig. 1 is shown the calibration curve for berberine chloride. It is visible that at different concentrations of berberine chloride $(1.016,2.54,5.08,7.62,10.16 \mathrm{mg} / \mathrm{ml})$ different absorbance values were recorded at $425 \mathrm{~nm}$ : 0.1764 , $0.4498,0.8577,1.1514,1.5514$. Both for $B$. vulgaris tincture and $B$. aquifolium tincture three measurements were done at $425 \mathrm{~nm}$ and the absorbance values were recorded for B. vulgaris and for B. aquifolium (Table 1).

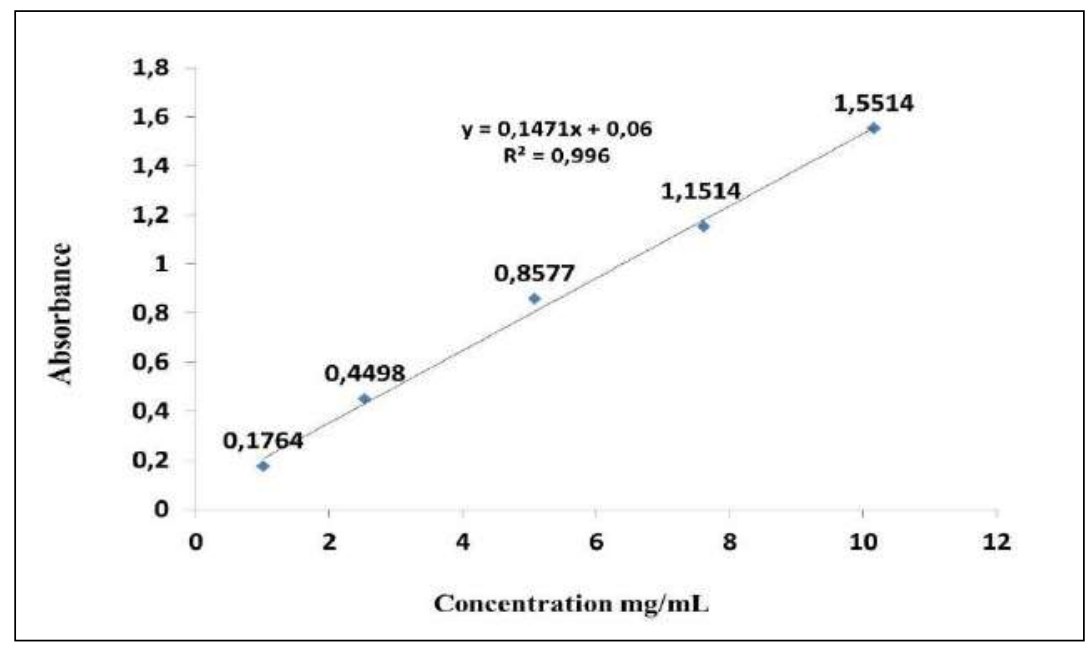

Figure 1. Calibration curve for berberine chloride at $425 \mathrm{~nm}$.

By the equation of a straight line $y=0.1471 \mathrm{x}+0.06$ could be established the alkaloid concentration expressed in berberine out of the Berberis sp tinctures, " $\mathrm{X}$ " representing concentration $(0.1471)$ and " $y$ " the area $\mathrm{c}=\mathrm{A}-0.06 / 0.1471$, where $\mathrm{c}=5 \mathrm{mg} / \mathrm{mL}$.

Table 1. Absorbance and alkaloid concentration expressed in berberine out of the B. vulgaris. and B. aquifolium tinctures

\begin{tabular}{|c|c|c|c|}
\hline Tested species & Sample & Absorbance & $\begin{array}{c}\text { Alkaloids concentration expressed } \\
\text { in berberine, } \mathbf{~ m g} / \mathbf{m l} \\
\text { c= A-0.06/0.1471 }\end{array}$ \\
\hline \multirow{3}{*}{ B. vulgaris } & 1 & 0.6966 & 4.327 \\
\cline { 2 - 4 } & 2 & 0.6430 & 3.963 \\
\cline { 2 - 4 } & 3 & 0.6772 & 4.195 \\
\hline & 1 & 0.8683 & $\Delta \mathrm{c}=4.161$ \\
\hline \multirow{3}{*}{ B. aquifolium } & 2 & 0.9132 & 5.494 \\
\cline { 2 - 4 } & 3 & 0.8505 & 5.80 \\
\hline \multicolumn{2}{|l}{} & & 5.373 \\
\hline
\end{tabular}

To each absorbance value corresponds a concentration value calculated after the formula: $\mathrm{c}=\mathrm{A}-0.06 / 0.1471$, where " $\mathrm{A}$ " is the specific absorbance of the tincture.
Concentrations mean $(\Delta c)$ represents the total quantity of alkaloids, expressed in berberine, from the two Berberis sp. tinctures. 
The highest concentration of alkaloids was obtained at $B$. aquifolium $(\Delta \mathrm{c}=5.555)$ than in B. vulgaris tincture $(\Delta c=4.161)$. This can be due to the presence of berberine, jatrorrhizine and magnoflorine, the main alkaloids found in relatively equal proportions in Berberis aquifolium, while Berberis vulgaris has as single main alkaloid: berberine.

2. Thin-layer chromatography analysis (TLC). The plate for TLC is split into three zones (I, M, S) in which specific coloured bands appear for the tested alkaloid and for other active compound out of Berberis extracts.

In the visible spectrum the TLC plate with the extract form the two analyzed Berberis species presents in zone I two orange bands and one faint orange band at each plant extract. In zone $M$ are highlighted one orange band of the standard, three orange bands for B. aquifolium and two orange bands and one faint orange for B. vulgaris (Fig. 2 (1).

In Fig. 2 the same bands are visible (2) and (3) which have appeared in zone I of silica gel plate: one blue band and two faint brownish-blue bands at each plant extract in TLC at $254 \mathrm{~nm}$. and at $365 \mathrm{~nm}$ appeared in zone I of silica gel plate: one dark blue band for B. aquifolium and one faint blue band for $B$. vulgaris and two faint blue bands at both extracts.

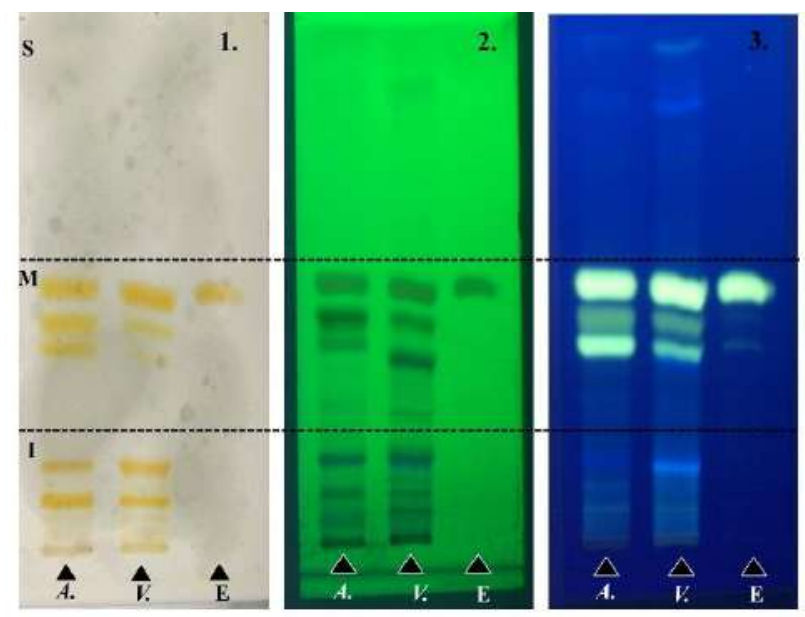

Figure 2. Thin layer cromatography of Berberis aquifolium (A.), Berberis vulgaris (V.) extracts and berberine chloride $(\mathrm{E}=$ control). 1 - visible spectra, 2 - at $254 \mathrm{~nm}, 3$ - at $365 \mathrm{~nm}$. $\mathrm{I}=$ inferior zone; $\mathrm{M}=$ median zone; $\mathrm{S}=$ superior zone of the plate.

In $\mathrm{M}$ zone is highlighted one dark brownish band of the standard, three dark brownish bands for B. aquifolium and two dark brownish bands and one faint brown for B. vulgaris visualised at $254 \mathrm{~nm}$. At $365 \mathrm{~nm}$ three bluephosphorescent bands have appeared for both extracts, while past the standard a single blue-phosphorescent band has appeared. These results confirm that in the two Berberis sp. extracts there is a certain quantity of berberine. The colour yellow and yellow-orange is characteristic to this alkaloid.

3. Analysis by HPLC with reversed phase. The chromatograms of the two species were overlapped in order to see better the difference as regards the peaks of berberine (Fig. 3).

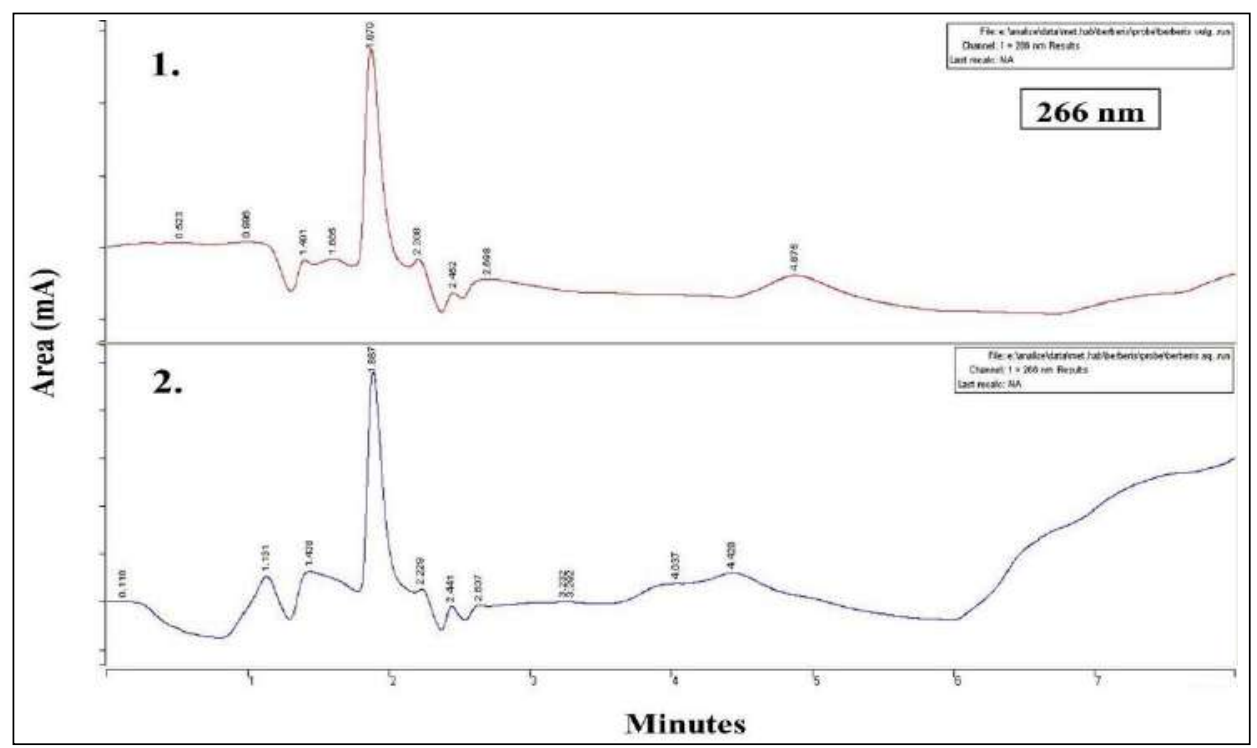

Figure 3. Overlapped chromatograms of berberine from the two Berberis sp. tinctures. 
It can be noticed that in chromatogram 1 (Berberis vulgaris) the peak has an aria of $1.870 \mathrm{~mA}$, while in chromatogram 2 (Berberis aquifolium) it has an area of $1.887 \mathrm{~mA}$

From the values of the areas the standard curve was drawn (Fig. 4) with the equation of a straight line: $y=3 E+0.7 x-2 E+0.6$, where " $y$ " is the aria and " $x$ " the concentration $(\mathrm{mg} / \mathrm{ml})$.

Form the equation of a straight line the concentration of berberine alkaloid $(\mathrm{mg} / \mathrm{ml})$ in the two analysed Berberis $s p$. tinctures was calculated (Table 2).

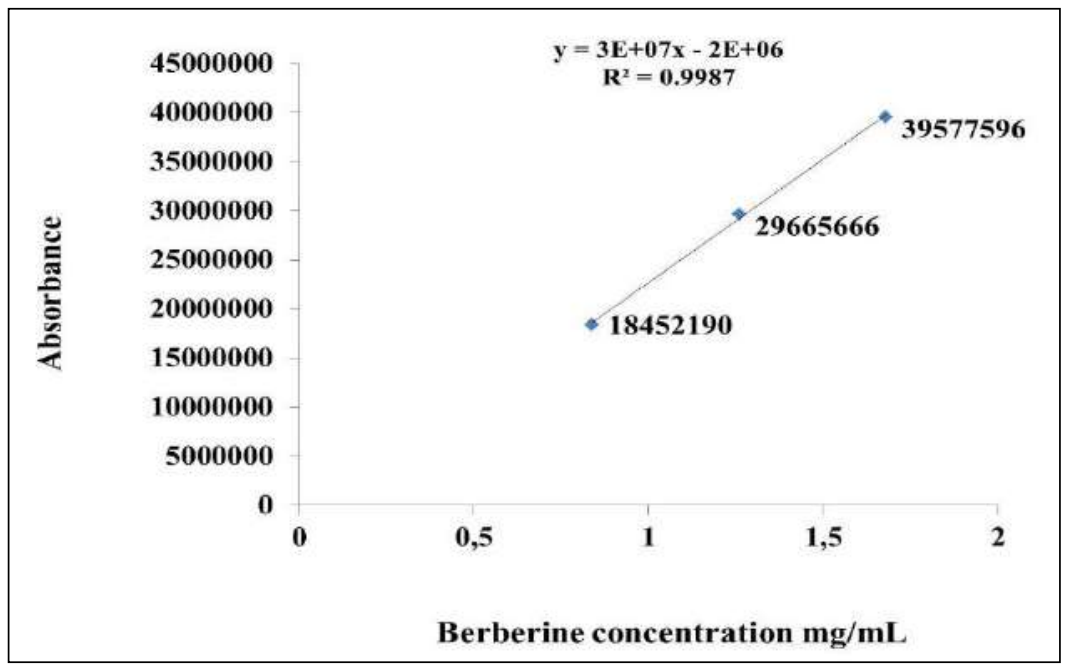

Figure 4. Berberine standard curve in reversed phase HPLC.

Table 2. Berberine concentration in Berberis sp. tinctures, expressed in $\mathrm{mg} / \mathrm{ml}$

\begin{tabular}{|c|c|c|}
\hline Area B. vulgaris & Area B. aquifolium & $C=\frac{A+2 \times 10^{6}}{3 \times 10^{7}}$, \\
\hline $\mathrm{A}_{B v}=39070732$ & $\mathrm{~A}_{B a}=13464614$ & $\mathrm{C}_{B v}=1.369 \mathrm{mg} / \mathrm{ml}$ \\
\cline { 2 - 3 } & & $\mathrm{C}_{B a}=0.515 \mathrm{mg} / \mathrm{ml}$ \\
\hline
\end{tabular}

In $B$. vulgaris tincture, the concentration of berberine is $1.369 \mathrm{mg} / \mathrm{ml}$, much higher than in $B$. aquifolium $(0.515$ $\mathrm{mg} / \mathrm{ml})$. The highest berberine concentration in $B$. vulgaris extract can show that berberine is more concentrated in the root and bark of barberry, being the main alkaloid of the plant. On the other hand, the lowest berberine concentration in B. aquifolium extract shows that in the plant there is berberine, but besides it there are also present other alkaloids like: jatrorrhizine and magnoflorine, having a tight association, protecting the plant against pathogen attack. The presence of these alkaloids in mahonia has inhibitory effects on certain bacteria and fungi almost equal to the one of berberine, some presenting an antibacterial and antifungal effect even stronger than this (eg. Jatrorrhizine and magnoflorine). Even more, the studies performed on this plant show how effective is the mother tincture in the treatement of deseases as plaque psoriasis or the antihiperlipidemic treatment (P. ANDRES \& G. CHANTALAT [12]; A. CICERO \& S. ERTEK [13]).

Comparing the results from spectrophotometry with reversed phase HPLC it turns out that, even if in B. vulgaris there is lower alkaloids concentration than in B. aquifolium, actually in common barberry there is bigger berberine concentration than in mahonia. Thus, it can be concluded that berberine is the essential secondary metabolite from $B$. vulgaris, having the role to protect it from stress and against microbial and fungic attack at the level of root and stem bark (H. DITTRICH \& T.K. KUTCHAN [19]; S. DHAMGAYE \& al [21]). This shows the importance of clinically testing berberine as powder, capsules, tinctures, ointment in different labs, for its antibacterial and antifungal effects and for its healing properties when is administred in the treatment of certain diseases (U. GIELER \& al [22]; M. CERNAKOVA \& D. KOSTALOVA [23]; FP [24]).

For these properties, berberine is produced in biotechnologies by semisynthesis or chemical synthesis in order to produce tinctures, unguents, capsules and powder for treating different diseases (H. FUKUI \& al [25]; H.K. POTUKUCHI \& al [26]; J. YIN \& al [27]). Due to the bacteria resistance to more antibiotics, the researchers are focusing on studying the antibacterial effects displayed by plant alkaloids for producing natural medicines with benefic effects also on the entire organism (P.J. FACCHINI \& al [28]; SINGH \& al [29]).

4. Testing the bacteria sensibility at Berberis sp. extracts. On the two plates innoculated with bacterial suspension of E. coli and S. aureus, 5 disk papers were applied, impregnated with plant extract and were put to incubation $24 \mathrm{~h}$. Then the results were evaluated, measuring in $\mathrm{mm}$ the inhibition zone appeared (Fig. 5). The samples were analysed regarding the sensibility in triplicate. 

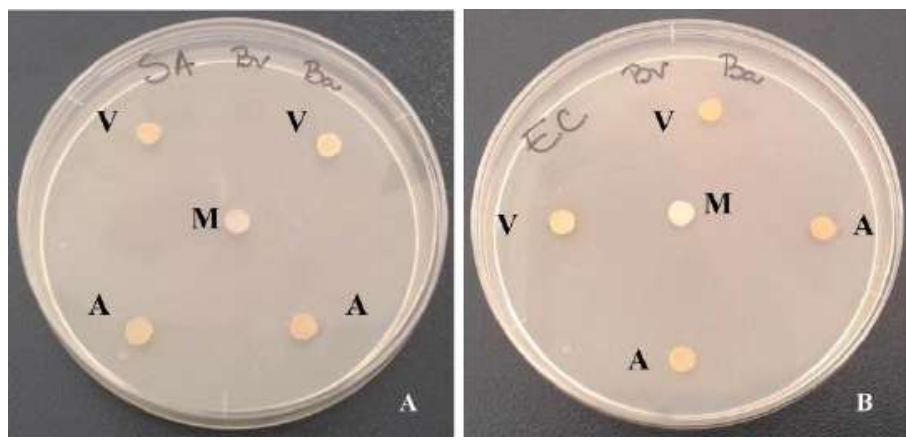

Figure 5. Applying disk papers on NA culture medium inoculated with A - Staphylococcus aureus, $\mathrm{B}-$ Escherichia coli $(\mathrm{M}=$ control (ethanol 70\%); V= TM Berberis vulgaris; $\mathrm{A}=\mathrm{TM}$ Berberis aquifolium)

After 24 incubation hours, the inhibition zones for the tested strains were drawn. At the Gram positive strain (Staphylococcus aureus) the sensibility is high at the two extracts compared to control, B. vulgaris presenting an inhibition of 10 and $11 \mathrm{~mm}$ and $B$. aquifolium having a higher inhibition, 11 and $12 \mathrm{~mm}$ (Fig. $6 \mathrm{~A}$ ). The control at $S$. aureus strain shows an inhibition of $8 \mathrm{~mm}$, much lower than the two extracts.

At the Gram negative strain, Escherichia coli, it can be noticed that the control had a $7 \mathrm{~mm}$ inhibition, and the two extracts had a higher inhibition. B. vulgaris tincture displayed an inhibition of $9 \mathrm{~mm}$ and $10 \mathrm{~mm}$, and tincture from $B$. aquifolium had an inhibition of $8 \mathrm{~mm}$ and $9 \mathrm{~mm}$ (Fig. 6 B).
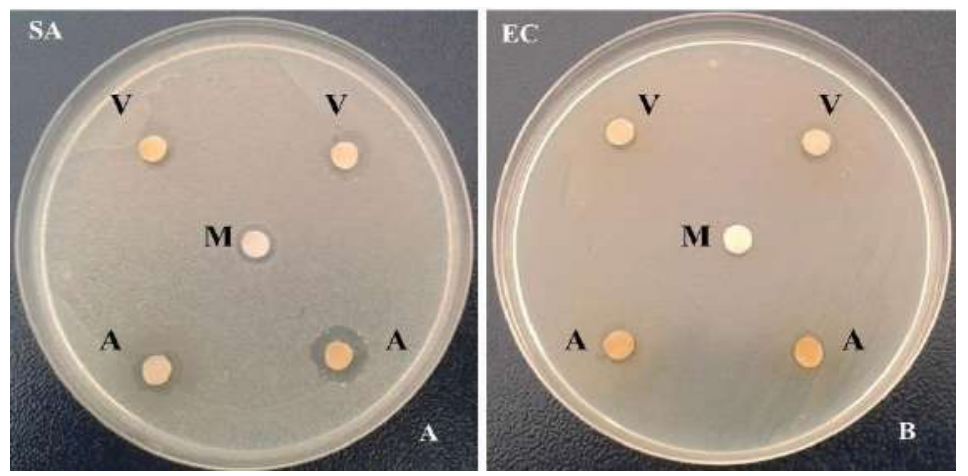

Figure 6. Bacterial sensibility of Staphylococcus aureus (A) and of Escherichia coli (B) at the disk papers with $B$. vulgaris and $B$. aquifolium at 24 incubation hours $(\mathrm{M}=$ control (ethanol $70 \%) ; \mathrm{V}=\mathrm{TM}$ Berberis vulgaris; $\mathrm{A}=\mathrm{TM}$ Berberis aquifolium).

B. vulgaris extract on $S$. aureus strain had an inhibition of $11 \mathrm{~mm}$ and $10 \mathrm{~mm}$. But on E. coli presented a higher inhibition than the B. aquifolium extract, $9 \mathrm{~mm}$ and $10 \mathrm{~mm}$ respectively. Thus, the extract from the common barberry bark of root and stem had a very good antimicrobial activity on both bacteria strain, showing how strong is berberine in this plant.
The control (ethanol 70\%) displayed a lower inhibition on both plates towards the two extracts, having an inhibition zone about $7 \mathrm{~mm}$ on $E$. coli and $8 \mathrm{~mm}$ on $S$. aureus plates. The highest antimicrobial activity was reached at Berberis aquifolium extract on Staphylococcus aureus strains, with $12 \mathrm{~mm}$ inhibition zone (Fig. 7).

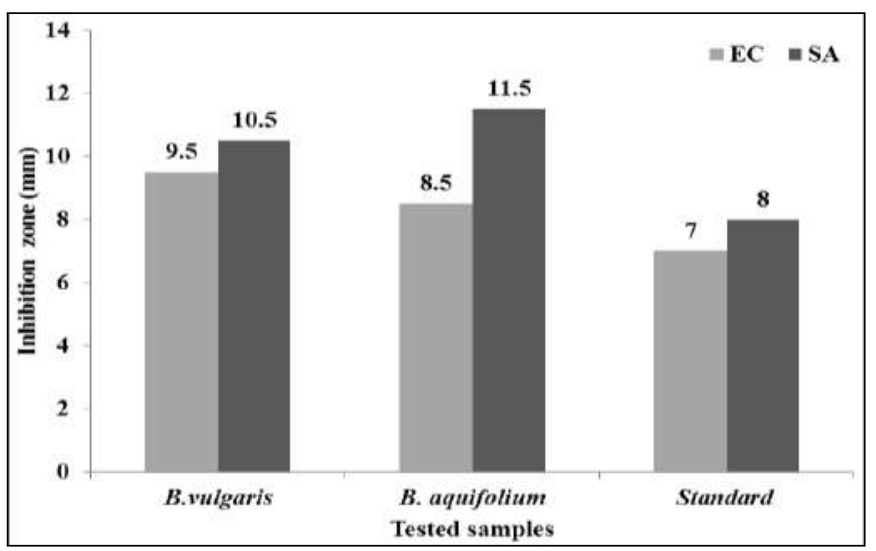

Figure 7. Diameter of inhibition zone $(\mathrm{mm})$ at Berberis vulgaris and Berberis aquifolium extracts on tested bacteria. 
The lowest antimicrobial activity belonged to the same extract, but at Escherichia coli strain inhibition zone was about $8 \mathrm{~mm}$. Thus $S$. aureus is more sensitive to mahonia ethanolic extract than $E$. coli, which is more resistant. This result could mean that a tincture or an ointment prepared from $B$. aquifolium could treat certain skin diseases caused by $S$. aureus.

Comparing the control and the two tested extracts, it turns out that $70 \%$ ethanol has an antibacterial effect, but not so strong as the tinctures from the two analysed plants. This is due to alkaloids in the two plants, more precisely, to berberine, this study further proving its efficiency. Even though the tincture contains $70 \%$ ethanol, the effect of inhibition is not entirely form alcohol, but much of it is due to berberine and the other active compounds from the extract. Berberine is a secondary metabolite from Berberis vulgaris and Berberis aquifolium, responsible for protecting the plant when it is subjected to a stress or a microbial attack (A. MITHOFER \& M.E. MAFFEI [30]; F.R. STERMITZ \& al [31]). B. vulgaris bark extract could serve as a viable biocontrol treatment alternative to conventional antifungal agents (M. PÂRVU \& al. [32]; M.D. NAJMEH $\&$ al [33]). The tincture preserved in $70 \%$ ethanol, mentains the alkaloid concentration within normal parameters and this way berberine from extract can succesfully inhibate certain strains of Gram negative and Gram positive bacteria.

\section{Conclusions}

Berberis vulgaris and Berberis aquifolium are two medicinal herb species spread throughout the world and are widely used as tinctures, extracts, ointments of the stem bark, root bark and the fruits are used as food for the big variety of active compounds. The main alkaloid which helps these two plants against a pathogen attack or in stress conditions is berberine. Berberine is an isochinoleinic alkaloid, found in the plant species belonging to Berberidaceae family. The alkaloid is located in rhizome, the stem bark and the root bark. BBE (berberin bridge enzyme) is the main ingredient for activating berberine biosynthesis.

By spectrophotometric analysis the total alkaloid concentration in the extracts was assessed, $4.161 \%$ for B. vulgaris and $5.555 \%$ for B. aquifolium.

Through TLC (thin layer chromatography) the presence of berberine in the two samples was checked, and the result was positive, recording three orange bands specific to the alkaloid for each tincture.

By HPLC with reversed phase (high phase liquid chromatography) was assessed the quantity of berberine in the two tinctures. By chromatograms, the alkaloid concentration in the two samples was assessed, $1.369 \mathrm{mg} / \mathrm{ml}$ for B. vulgaris and $0.515 \mathrm{mg} / \mathrm{ml}$ for B. aquifolium.

Both tinctures were tested on a Gram negative bacteria, Escherichia coli, and one Gram positive, Staphylococcus aureus. The extracts exhibited an inhibition between $10 \mathrm{~mm}$ and $12 \mathrm{~mm}$ at $S$. aureus between $8 \mathrm{~mm}$ and $10 \mathrm{~mm}$ at $E$. coli, due to berberine and the other main alkaloids found in the bark of these plants.

\section{Acknowledgments}

We thank to Lecturer Endre Jakab from Biology and Geology Faculty, Cluj-Napoca, Romania, for bacterial strains.

\section{References}

1. M. IMANSHAHIDI, H. HOSSEINZADEH. Pharmacological and therapeutic effects of Berberis vulgaris and its active constituent, berberine. Phytotheraphy Research, 22 999-1012 (2008).

2. V. JYOTHILAKSHMI, P. KALAISELVI, A. KHURANA, A. KUMAR, D. NAYAK, G. THELLAMUDHU. Preliminary investigation on ultra high diluted $B$. vulgaris in experimental urolithiasis. Homeopathy 102:3 172-178 (2013).

3. F. CLINOVSCHI. Dendrology. In: Universitatea Suceava (Ed.), (2005), pp. 171-172 (in Romanian).

4. J. KLOSS. Health care herbs. In: Cornint (Ed.), Bucharest (2010), pp. 47 (in Romanian).

5. L.S. MUNTEAN. Cultivated and wild medicinal herbs treatice. Risoprint (Ed.) Cluj-Napoca (2007) (in Romanian).

6. J.S. FRALISH, S.B. FRANKLIN. Taxonomy and ecology of woody plants in North American forests. In: Wiley (Ed.) (2002), pp 194-195.

7. D.E. JONES. Poison arrows: North American Indian hunting and warfare. In: University of Texas Press Austin (Ed.) (2009), pp. 14.

8. C. ROSS. Invasion success by plant breeding: evolutionary changes as a critical factor for the invasion of the ornamental plant Mahonia aquifolium. In: Vieweg Teubner Research (Ed.), Germany, (2009), pp. 6-7.

9. D. KINDERSLEY, C. BRICKELL (Eds.). RHS A-Z Encyclopedia of garden plants, United Kingdom (2008), pp 1136.

10. K. GHEDIRA, P. GOETZ, Mahonia aquifolium (Pursh) Nutt. (Berberidaceae): Mahonia. Phytotherapie 12 185-193 (2014).

11. S. FAZEL, M. HAMIDREZA, G. ROUHOLLAH, M. VERDIANRIZI. Spectofotometric determination of total alkaloids in some Iranian medicinal plants. J. Applied Horticulture 12:1 69-70 (2010).

12. P. ANDRES, G. CHANTALAT. Combinations of Indigo naturalis and berberine and uses thereof. Patent Application Publication, no. 0243354 A1 1-6 (2014).

13. A. CICERO, S. ERTEK. Berberine: metabolic and cardiovascular effects in preclinical and clinical trials. Nutrition and Dietary Supplements 1, 1-10 (2009).

14. HAB (Homöopathisches Arzneibuch). Deutscher Apotheker Verlag, Germany (2009).

15. HAB (Homöopathisches Arzneibuch). Deutscher Apotheker Verlag, Germany (2010).

16. G.V. SRINIVASAN, K.P. UNNIKRISHNAN, A.B. REMA SHREE, I. BALACHANDRAN. HPLC Estimation of berberine in Tinospora cordifolia and Tinospora sinensis, Indian J Pharm Sci., 70:1 96-99 (2008). 
17. R.M. ATLAS. Handbook of Microbiological Media, $4^{\text {th }}$ edition. In: CRC Press (Ed) New York (2010).

18. R. CARPA, M. DRĂGAN-BULARDA, V. MUNTEAN. General Microbiology-Lab Practices. In: Presa Univ. Clujeană (Ed.) Cluj-Napoca (2014) (in Romanian).

19. H. DITTRICH, T.K. KUTCHAN. Molecular cloning, expression, and induction of berberine bridge enzyme, an enzyme essential to the formation of benzophenanthridine alkaloids in the response of plants to pathogenic attack. Proceed. Nat. Acad. Sci. 88, 99699973 (1991).

20. G. PAUN, E. NEAGU, V. MOROEANU, O. UNGUREANU, R. CRETU, E. IONESCU, C.E. TEBRENCU, R. IONESCU, I. STOICA, G.L. RADU. Phytochemical analysis and in vitro biological activity of Betonica officinalis and Salvia officinalis extracts, Romanian Biotechnological Letters, 22: 4, 12751-12761 (2017).

21. S. DHAMGAYE, F. DEVAUX, P. VANDEPUTTE, N.K. KHANDELWAL, D. SANGLARD, G. MUKHOPADHYAY, R. PRASAD. Molecular mechanisms of action of herbal antifungal alkaloid berberine, in Candida albicans. PLoS One 9:e104554. doi:10.1371/ journal.pone.0104554 (2014).

22. U. GIELER, M. HEGER, A. WETH. Mahonia aquifolium - a new type of topical treatment for psoriasis. J. Dermatolog. Treat. 6 31-34 (1995).

23. M. CERNAKOVA, D. KOSTALOVA. Antimicrobial activity of berberine - a constituent of Mahonia aquifolium. Folia Microbiologica 47:4 375-378 (2002).

24. FP (French Pharmacopoeia). Common barberry for homeopathic preparations - Berberis vulgaris. ANSM, France (2009).

25. H. FUKUI, Y. KOBAYASHI, M. TABATA. Berberine production by batch and semi-continuous cultures of immobilized Thalictrum cells in an improved bioreactor. Plant Cell Reports 7:4 249-252 (1988).

26. H.K. POTUKUCHI, T.J. DONOHOE, A.P. SPORK. Palladium-catalyzed $\alpha$-arylation of carbonyls in the $d e$ novo synthesis of aromatic heterocycles. Org. Biomol. Chem. 13 4367-4373 (2015).

27. J. YIN, J. YE, W. JIA. Effects and mechanisms of berberine in diabetes treatment. Acta Pharmaceutica Sinica B 2:4 327-334 (2012).

28. P.J. FACCHINI, S.U. PARK, N. SAMANANI. Cell type-specific localization of transcripts encoding nine consecutive enzymes involved in protoberberine alkaloid biosynthesis. The Plant Cell 17 915-926 (2005).

29. J. SINGH, S. DUGGAL, N. KAUR, A. SINGH. Berberine: Alkaloid with wide spectrum of pharmacological activities. J. Natural Products 3 64-75 (2010).

30. A., MITHOFEI, M.E. MAFFEI. General mechanisms of plants defense and plant toxins. Toxicology. In: Springer Netherlands (Ed.) (2016) pp. 1-22.

31. F.R, STERMITZ, P. LORENZ, J.N. TAWARA, L.A. ZENEWICZ, K. LEWIS. Synergy in a Medicinal Plant: Antimicrobial action of berberine potentiated by 5'-methoxyhydnocarpin, a multidrug pump inhibitor. Proceed. Nat. Acad. Scie. USA 97:4 1433-1437 (2000).

32. M. PÂRVU, A.E. PÂRVU, L. BARBU-TUDORAN, L. VLASE, M. TĂMAŞ, O. ROŞCA-CASIAN, O. PERSECA, A.M. MOLNAR. Changes in Botrytis cinerea conidia caused by Berberis vulgaris extract. Not. Bot. Hort. Agrobot. Cluj 38:3 15-20 (2010).

33. M.D. NAJMEH, S. SOODABEH, R.G. AHMAD, K.M. MAHDIEH. Phytochemistry and Pharmacology of Berberis species. Pharmacogon. 8:15 8-15 (2014). 